\title{
Simulation of the Incremental Conductance Algorithm for Maximum Power Point Tracking of Photovoltaic System Based On Matlab
}

\author{
Parween R.Kareem \\ Department of Electrical tech. Haweeja Tech. Inst., Northern Technical University \\ parweenraheem3@gmai.com
}

\begin{abstract}
Due to the urgent need to make maximum use of electrical power generated from the Photo-Voltaic System (PVS) solar panels, several techniques have been developed for this purpose. Maximum Power Point Tracking (MPPT) algorithm raises the efficiency of PVS's. Simulation of the complete (PVS) possesses the ability of MPPT is present in this paper. The approved PVS consists of a PV array, DC-DC Boost Converter and MPPT algorithm using Incremental Conductance Method (INC). All parts of the system were simulated programmatically using MATLAB. The obtained Results showed the efficiency of the algorithm used to extract the maximum power regardless of changes in solar radiation and cell's temperature.
\end{abstract}

Keywords: PV Module, MPPT, Incremental Conductance (INC) Algorithm.

\section{Paper History:}

(Received: 16/5/2017; Accepted: 6/11/2017)

\section{Introduction}

Due to the worsening of global warming and environmental changes as a result of increased greenhouse gas emissions since the beginning of the Industrial Revolution; as well as a decrease in traditional energy resources such as coal and oil and gas; On the other hand, increasing world demand for energy due to increased population density; become necessary to look for alternative sources of energy [1, 2, 3]. Solar energy can be converted into electric power according to the photovoltaic conversion mechanism. Photoelectric conversion is intended to convert solar or optical radiation directly into electrical energy by photovoltaic cells. As is known, some materials that conduct photovoltaic conversion are called semiconductors such as silicones, germanium, Edit the electrons of these metals and produce electrical energy [4]. Solar energy is one of the best among all the sources of renewable energy because it is clean, environmentally friend [5]. But it faced a problem of change of electric power generated by the PV cell due to changing ambient environmental conditions (solar radiation and temperature) [6]; However, the discontinuity of solar energy during the day which is only available to certain hours in a day which causes a problem in the process used, as results of temperature and radiation variation rapidly, the produced voltage change and becomes unstable as well as the produced power. Therefore it is necessary to track the maximum power point to extract maximum energy from the photovoltaic (PV) module system and transferring that power to the load [7].

In order to avoid ambiguity in the term of tracking, it is necessary to distinguish between the panel tracking and MPPT, Panel tracking is driven by the system of moving and tracking the sun itself, This system depends on a set of sensors that track the daily movement of the sun; and a motor that moves the panels so that they face the disk of the sun,

achieves the greatest solar radiation from the sun on the panels [8]. The second system is MPPT, it is a tracking device that has nothing to do with moving the panel, While it is using an electronic system working to change an electrical operating point [7].

There are many techniques used to track maximum power point of the photovoltaic system such as Incremental conductance, Perturb and Observe $(\mathrm{P} \& \mathrm{O})$, and Constant Voltage technique and others [4], in this research Incremental Conductance Method, is used, and it represented programmatically using MATLAB. Figure 1 show the total block diagram of the used system. 


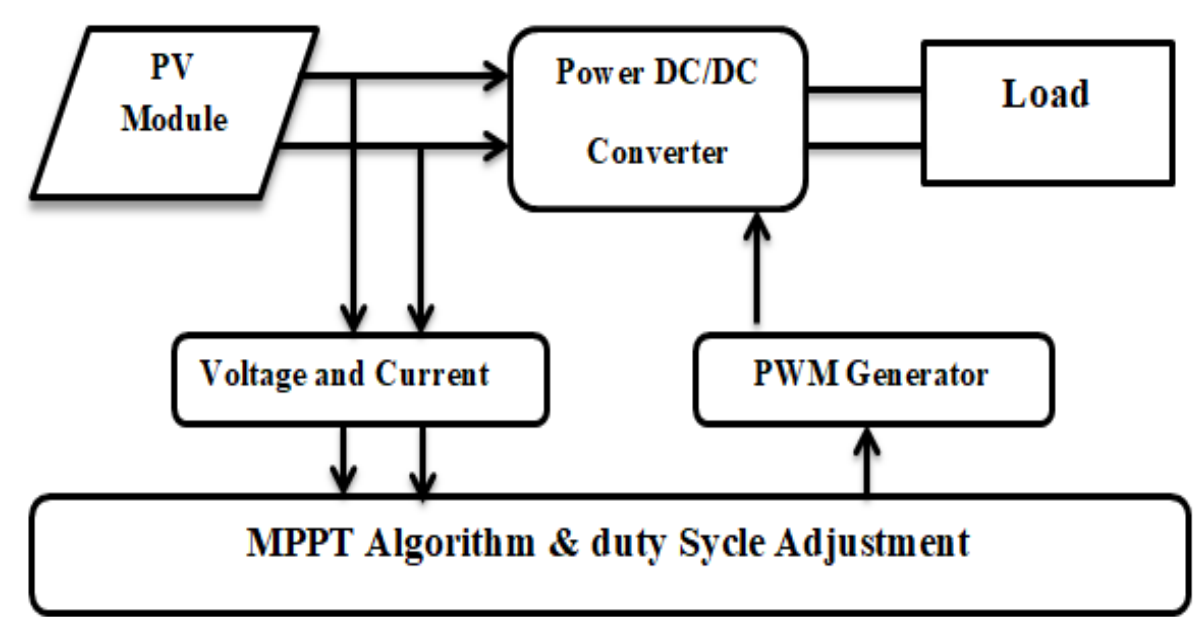

Figure 1: Overall block diagram

\section{Modeling of Photovoltaic Cell:}

The main part of PV module is the PV cell, a number of these cells arranged in series and parallel style to configure the module. PV module converts sunlight into electrical energy [7]. The I-V and P-V characteristics of PV modules depend fundamentally on solar irradiance and temperature of the cell [4]. Figure 2 and Figure 3 shows V-I and P-V characteristics respectively of $\mathrm{PV}$ array for various radiation at a cell's temperature of $25 \mathrm{oC}$, whereas Figure 4 and Figure 5 shows V-I and P-V characteristics respectively of PV array for various cell's temperature at radiation of $1000 \mathrm{w} / \mathrm{m} 2$, These characteristics were obtained from the simulated model of PV module. The equivalent circuit model of a single-diode model showed in Figure 6, a mathematical equation of a Photovoltaic solar cells module which characterizes the I-V characteristics are given by $[4,7]$ :

$$
\begin{aligned}
I_{p h} & =\frac{\left[I_{S C r}+K_{i}(T-298)\right]}{1000} * \lambda \\
I_{r s} & =I_{S C r} /\left[e^{\left({ }^{q V_{O C} / N_{S} K A T}\right)}-1\right]
\end{aligned}
$$

$$
\begin{aligned}
& I_{o}=I_{r s}\left[\frac{T}{T_{r}}\right]^{3} e^{\left[\frac{q \times E_{g o}}{B K}\left\{\frac{1}{T_{r}}-\frac{1}{T}\right\}\right]} \\
& I_{P V}=N_{P} * I_{P}-N_{P} * I_{O}\left[e^{\left(q\left(V_{P V}+I_{P V} * R_{S} / N_{S} A K T\right)\right.}-1\right] \text { (4) }
\end{aligned}
$$

VPV and IPV: output voltage and current of PV module respectively.

$\operatorname{Tr}$ and $\mathrm{T}$ : reference and operating temperature respectively.

Iph: generated current in a PV module (A)

Io: PV module saturation current (A)

$\mathrm{A}=\mathrm{B}$ : ideality factor

$k$ : Boltzmann constant

q: Electron charge

$R_{S}$ : series resistance of a PV module

ISCr: the PV module short-circuit current at 25 ${ }^{\circ} \mathrm{C}$ and $1000 \mathrm{~W} / \mathrm{m} 2$

$\mathrm{Ki}$ : short-circuit current temperature coefficient

$\lambda$ : Solar irradiance

Ego: band gap of silicon

$\mathrm{Ns}, \mathrm{Np}$ : number of series and parallel connected cells respectively 


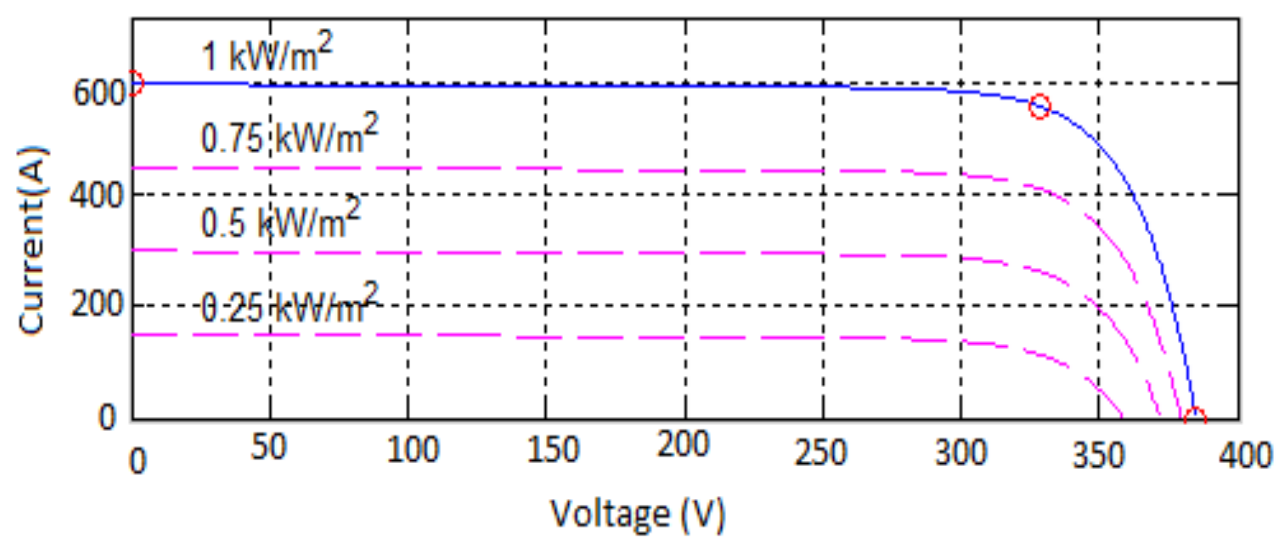

Figure 2; V-I characteristic for PV array influenced by solar illumination at $25^{\circ} \mathrm{c}$

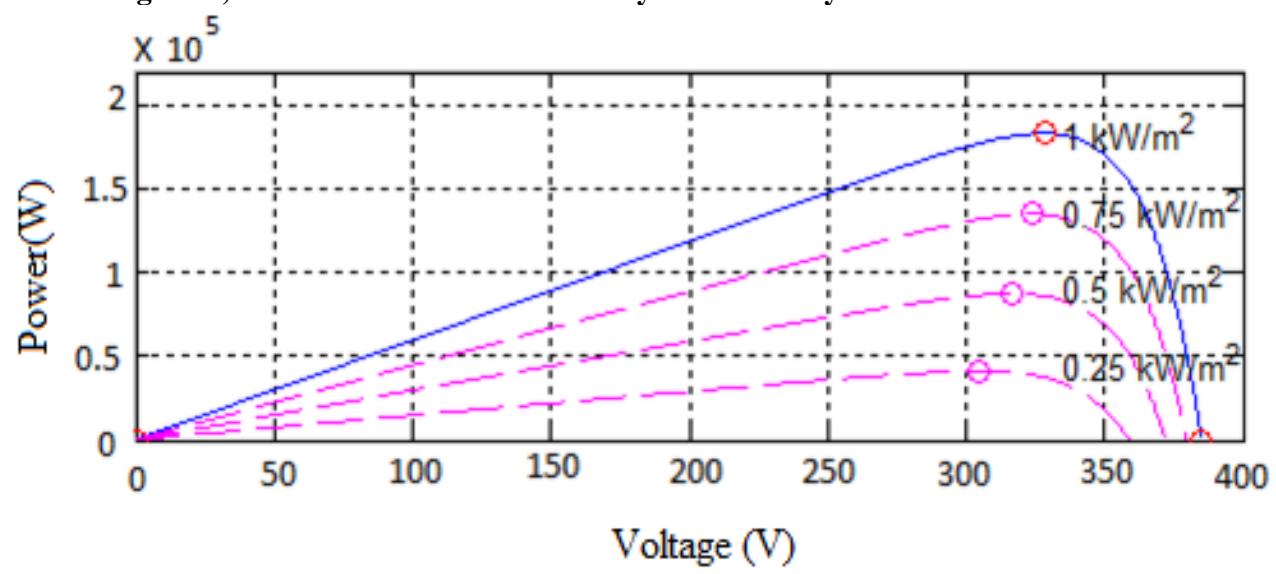

Figure 3: P-V characteristic for PV array influenced by solar illumination at $25^{\circ} \mathrm{c}$

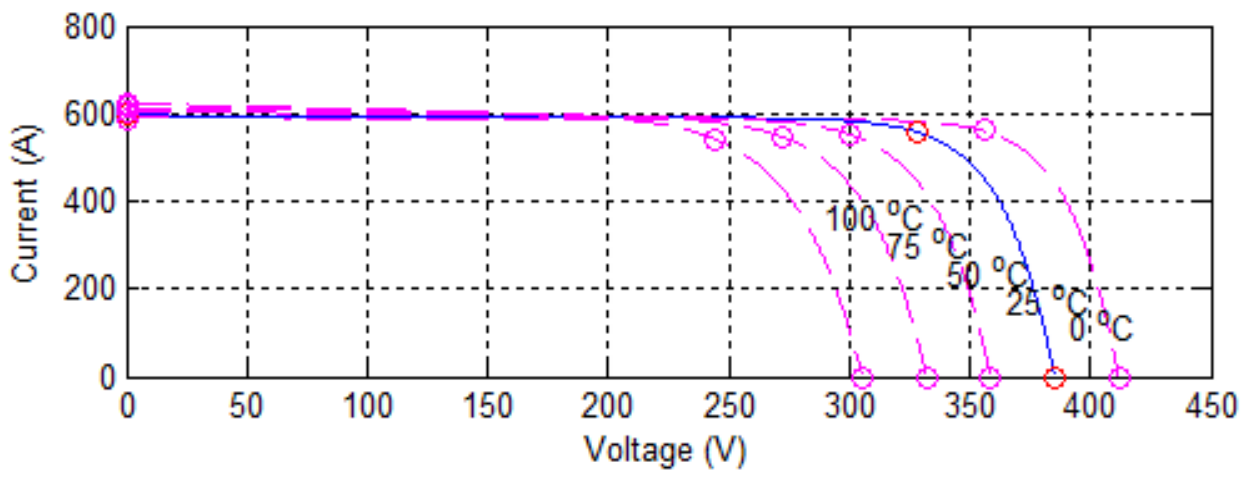

Figure 4: V-I characteristic for PV array influenced by temperature at radiation $1000 \mathrm{w} / \mathrm{m}^{2}$

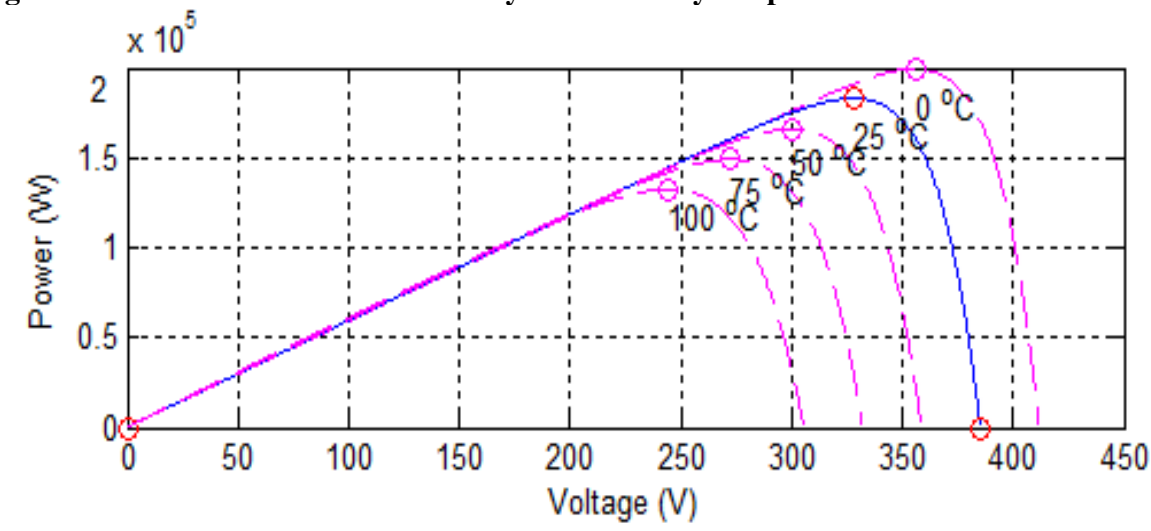

Figure 5: P-V characteristic for PV array influenced by temperature at radiation $1000 \mathrm{w} / \mathrm{m}^{2}$ 


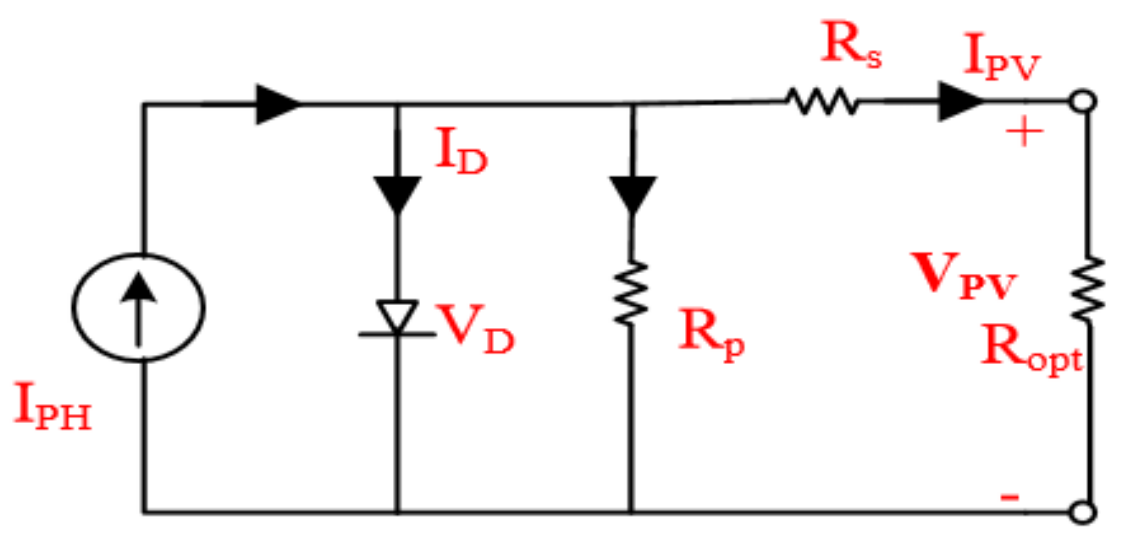

Figure 6: Single- diode circuit model of PV cell

\section{Incremental-Conductance MPPT Algorithm}

It is one of the algorithms that used to increase the efficiency of solar panels in converting solar energy into electrical energy; in this method, two sensors are used to sense PV array's output voltage and current [9]. It is use
$\mathrm{dI} / \mathrm{dV}$ to calculate the indication of $\mathrm{dP} / \mathrm{dV}$. When $\mathrm{dI} / \mathrm{dV}$ is equal to $(-\mathrm{I} / \mathrm{V})$ the algorithm realize that MPP has achieved and there it finish and returns the conformable value of operating voltage for MPP [2, 9]. Figure 7 Show flow chart of used algorithm [3].

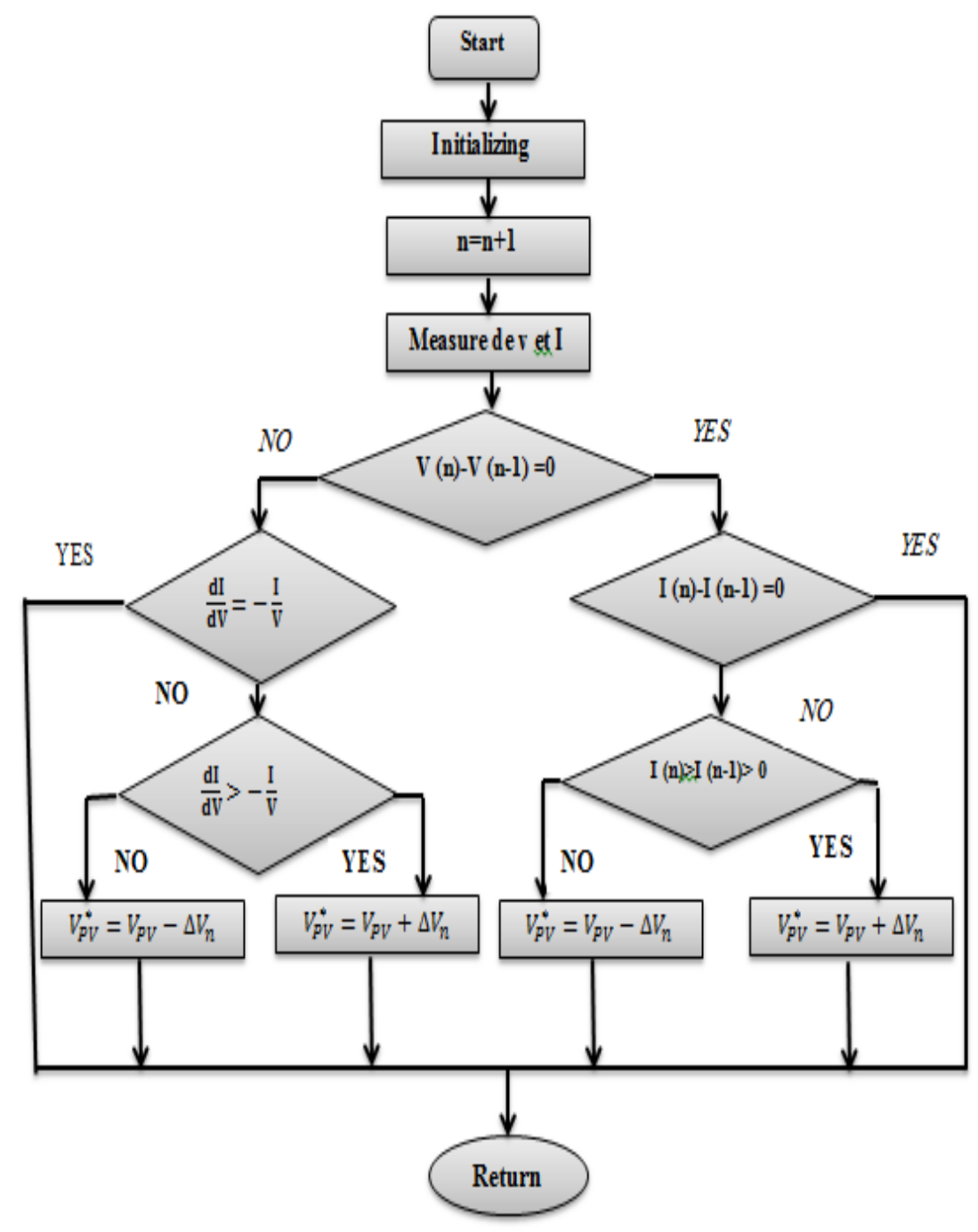

Figure 7: Flow chart of Incremental Conductance Method 
Panel's power is [9]:

$P=V * I$

The differentiation with regard to voltage is:

$$
\begin{aligned}
& \frac{d P}{d V}=d(V * I) \\
& \frac{d P}{d V}=V * \frac{d I}{d V}+I
\end{aligned}
$$

(7)

The condition at MPP equal to 0 zero is:

$$
\frac{d P}{d V}=0
$$

Substituting Equation 8 in 7 we result in Equation 9

$$
\begin{aligned}
& 0=V * \frac{d I}{d V}+I \\
& \frac{d I}{d V}=-\frac{I}{V}
\end{aligned}
$$

The principle of above algorithm is based on the comparison between the ends of equation 10 . In the case of Inequality change voltages to zero; there is a comparison occurs between incremental conductance and instantaneous conductance. If their values are equal, then it gets termination and returns the required value. If not, both must equally by rising or reducing

reference voltage. This point keeps its value as soon as it reaches the maximum power point until occurring changes in solar radiation and/or temperature [9].

\section{DC-DC Power Converter}

Due to the changes in temperature and radiation through the day, D.C voltage obtained from PV module was inconstant; it is converted into a regulated voltage using boost D.C-D.C converter to raise the output voltage [10].In fact, tracking of the maximum power point is a load matching trouble .DC to DC power converter is wanted for the match the panel's input resistance with the load resistance by modifying the duty cycle [11]. The boost converter is used here in this work, Figure 8 Show the boost converter circuit diagram [12]. It notes the Boost output voltage is:

$$
V_{\text {out }}=\frac{V_{\text {in }}}{1-D}
$$

$V_{\text {out }}$ : Output voltage

$V_{\text {in }}:$ input voltage $(\mathrm{V})$

D: duty cycle where its value varies between

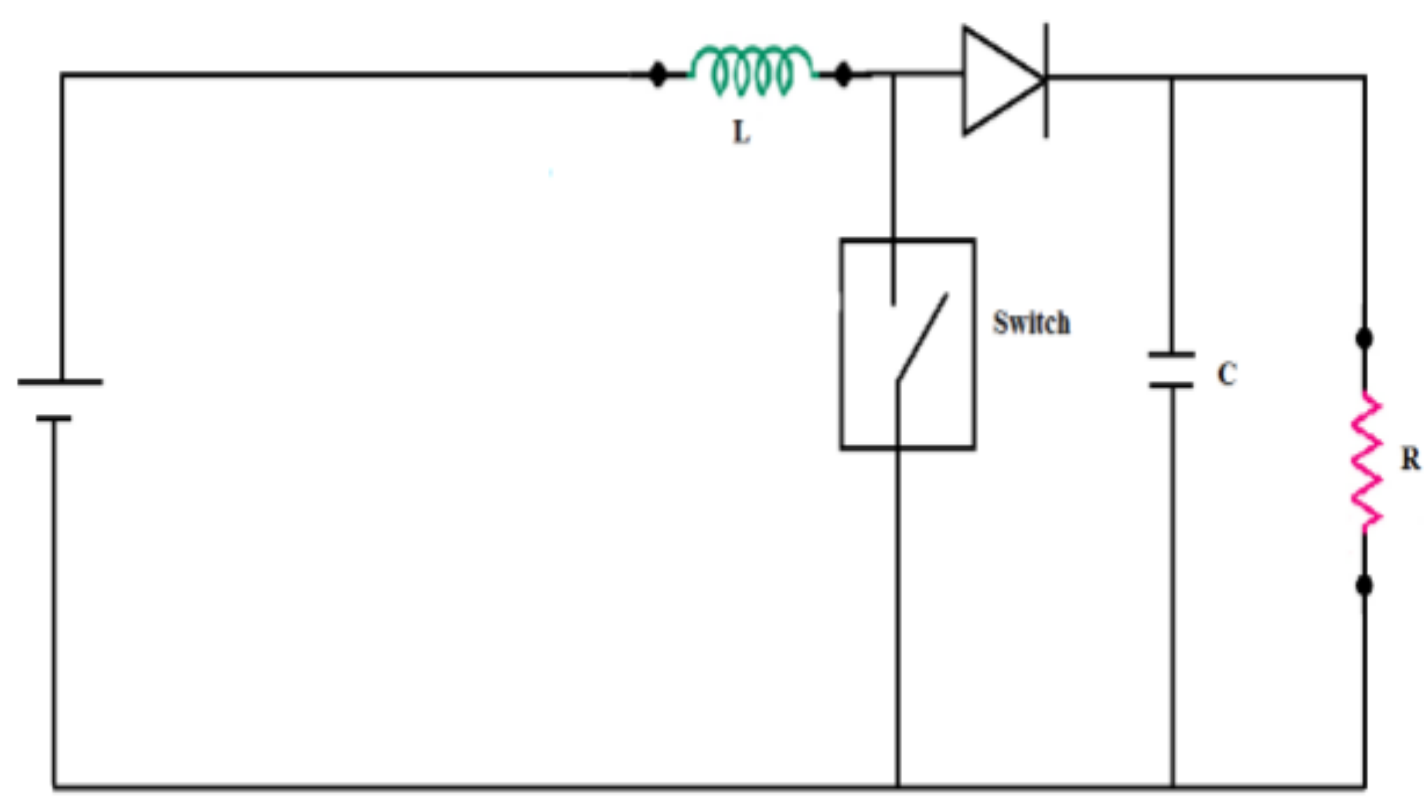

Figure 8: Circuit diagram of a Boost Converter

\section{Simulation Results and Discussion}

Figure 9 Illustrate the basic block diagram of the system presented in this research which is modeled in Matlab. PV array and the incremental conductance MPPT algorithm have been simulated in Matlab/ Simulink as shown in Figures 10, 11 respectively.

Figure 12 Presents the solar irradiance. The variation of solar irradiance was modeled for the 
purpose of examining the system's work, the temperature is set at $40{ }^{\circ} \mathrm{C}$, and the sun irradiance levels is varied with three levels. The first level of illumination is set at $1000 \mathrm{~W} / \mathrm{m}^{2}$, at the time $0.4 \mathrm{~s}$ the solar irradiation level pass to $600 \mathrm{~W} / \mathrm{m}^{2}$. Finally, radiation stabilizes at 800 $\mathrm{W} / \mathrm{m}^{2}$ in the second $0.7 \mathrm{~s}$ up to $1 \mathrm{~s}$. Figure 13 to 15 shows the results of the output power, voltage and current of the PV system respectively; it notes from the obtained results the relationship between the irradiance and the output power of the PV panel and shows the performance of the boost converter. It is observing a noticeable effect of irradiance's variation on system's operation where it is noted that the power produced by photovoltaic array increases as solar radiation increases and vice versa.

In order to study the effect of temperature change on the system work, the value of solar radiation is set at $1000 \mathrm{w} / \mathrm{m}^{2}$, and the tempreture levels is varied with two levels. The first level of tempreture is set at $20^{\circ} \mathrm{c}$, at the time $0.4 \mathrm{~s}$ the tempreture level pass to $60^{\circ} \mathrm{c}$, Figure 15 Presents the variation of tempreture, whereas the results of the output power, voltage and current of the PV system respectively for this case are show in Figure 16 to 19 , it is observe the power produced by photovoltaic array decreases as temperature increases and vice versa.

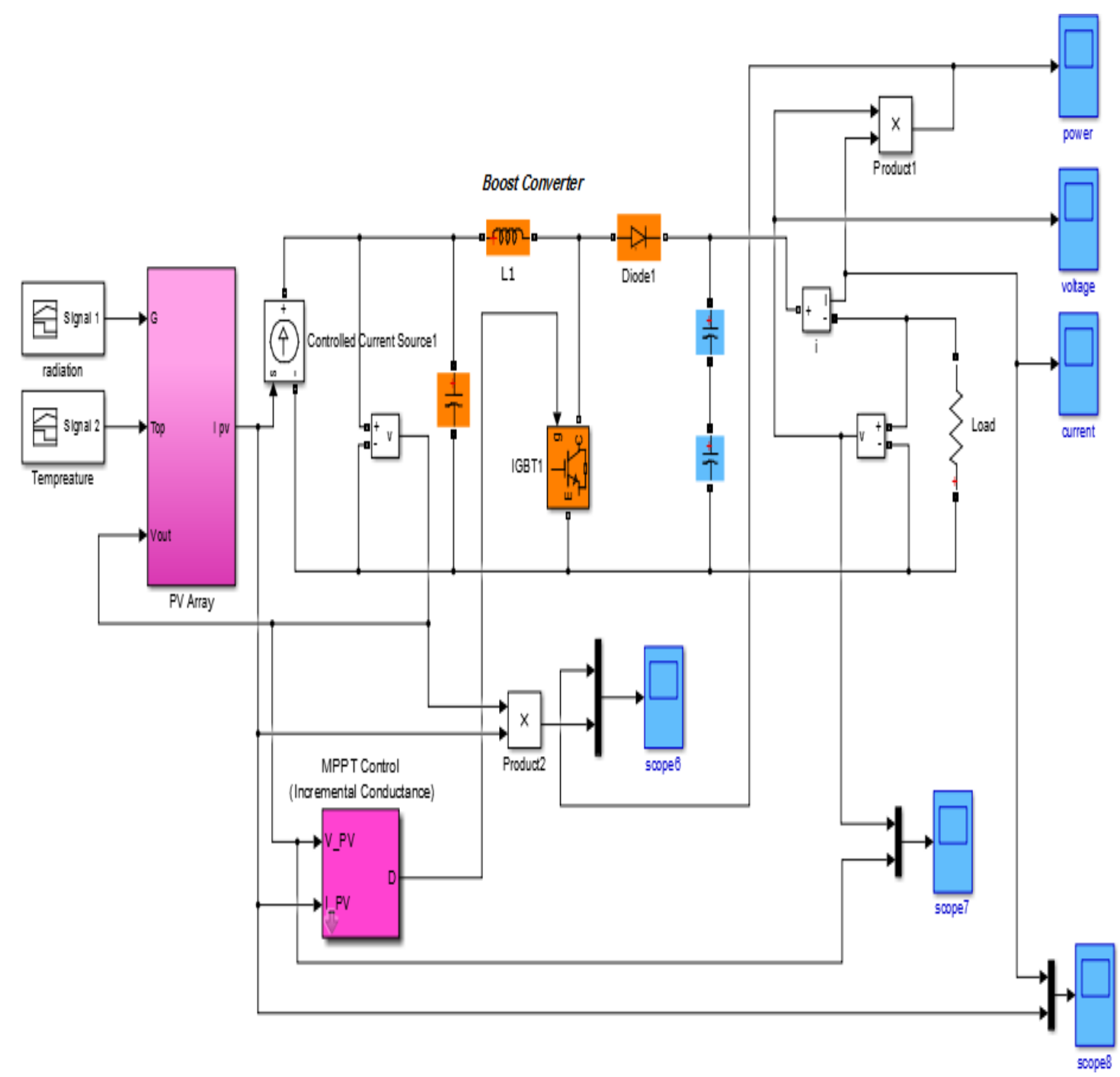

Figure 9: Simulink model of PV energy system 


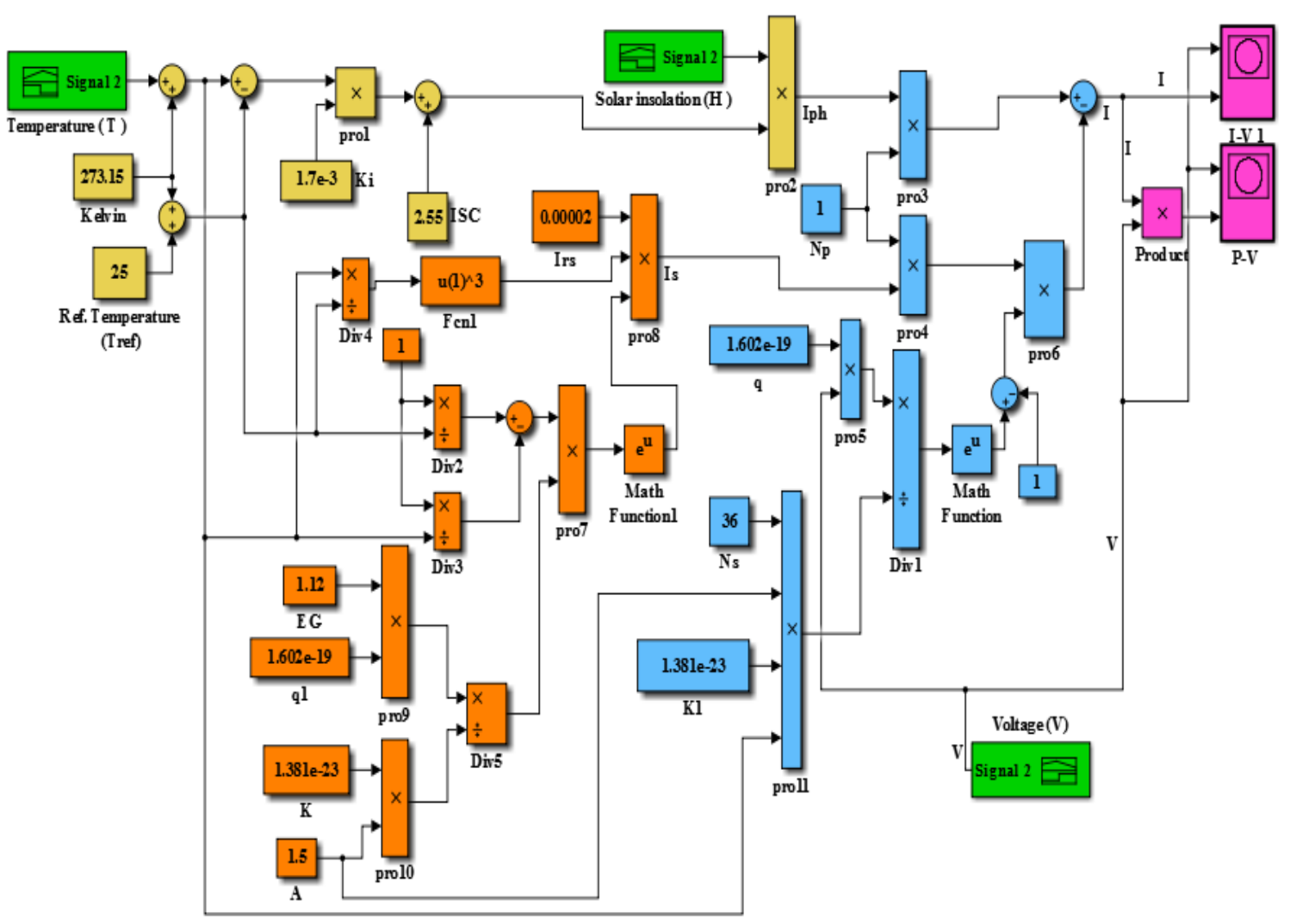

Figure 10: Simulink Model of PV cell

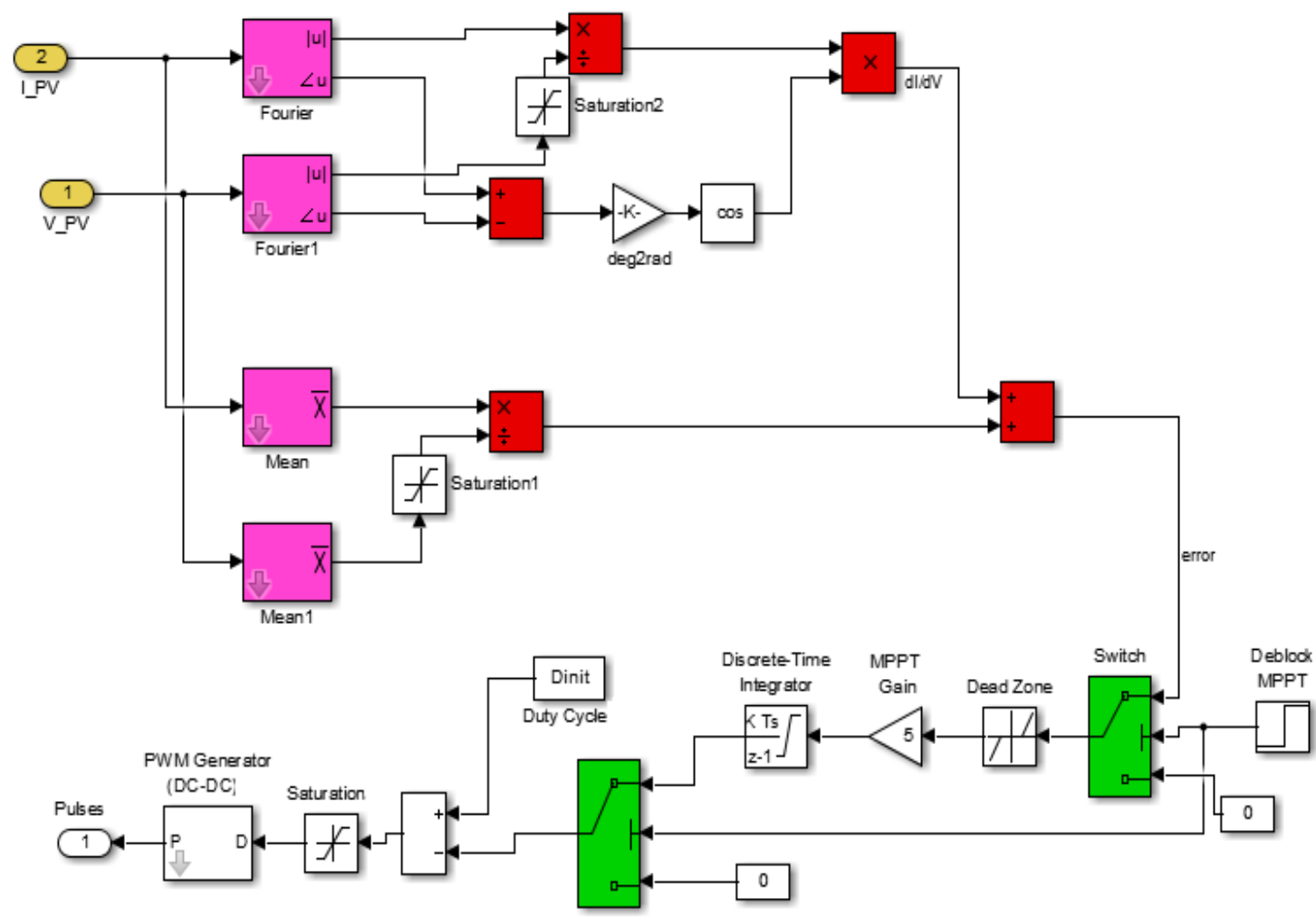

Figure 11: Simulink model of Maximum power point tracking by incremental conductance method 


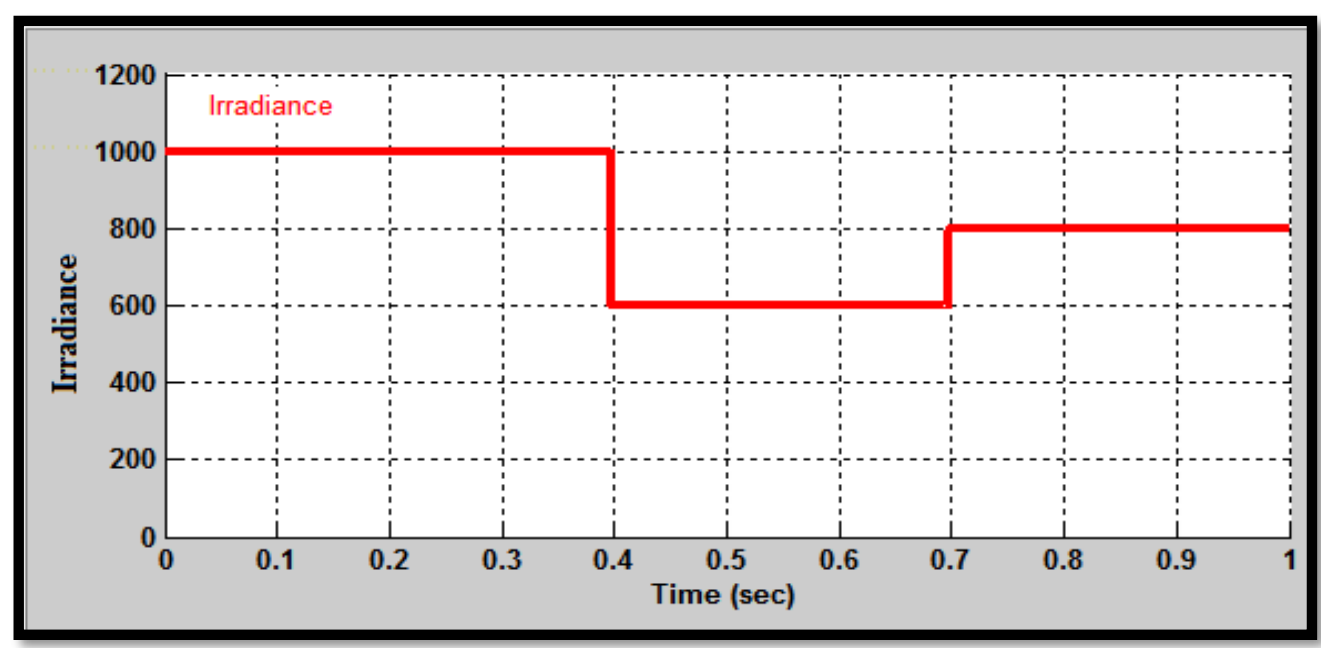

Figure 12: Variation of sun radiation

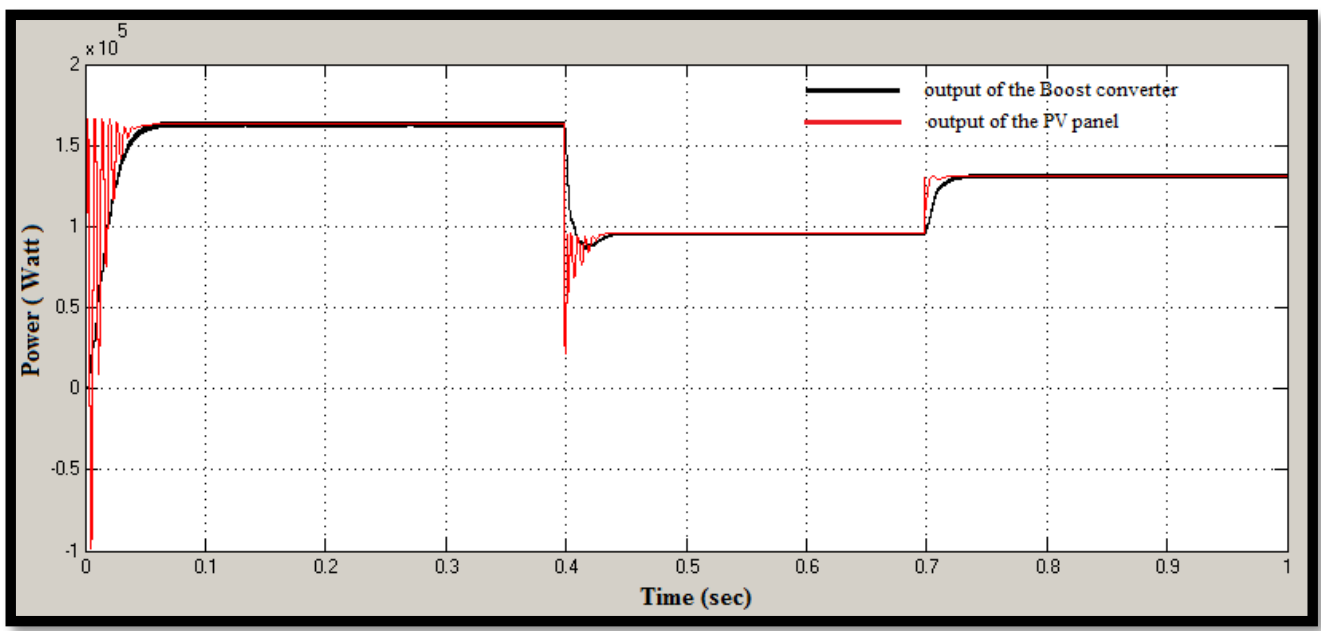

Figure 13: Output power of the Boost converter and output voltage of the PV panel

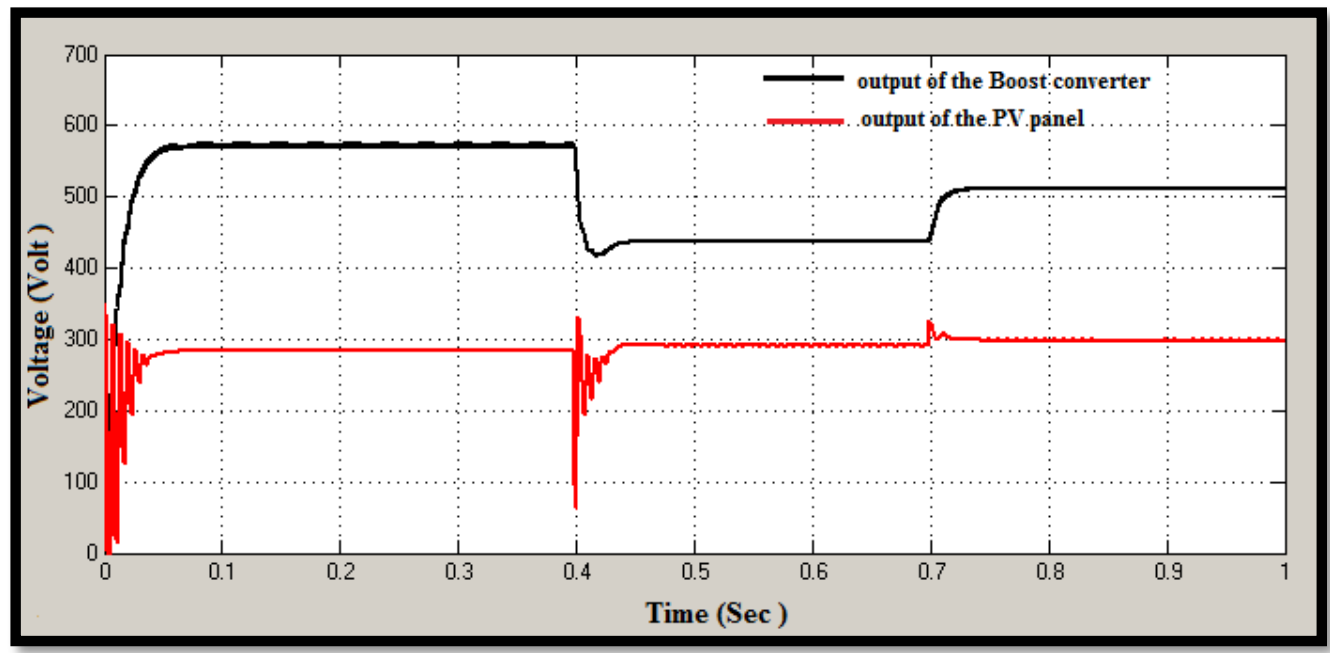

Figure 14: Output voltage of the Boost converter and output voltage of the PV panel 


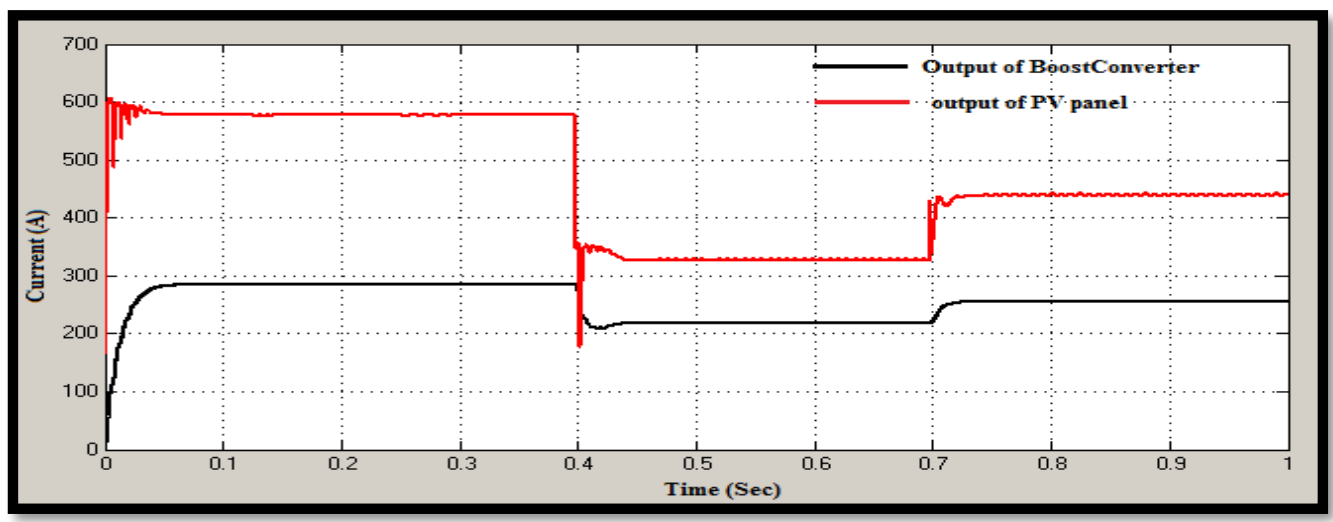

Figure 15: Output current of the Boost converter and output current of the PV panel

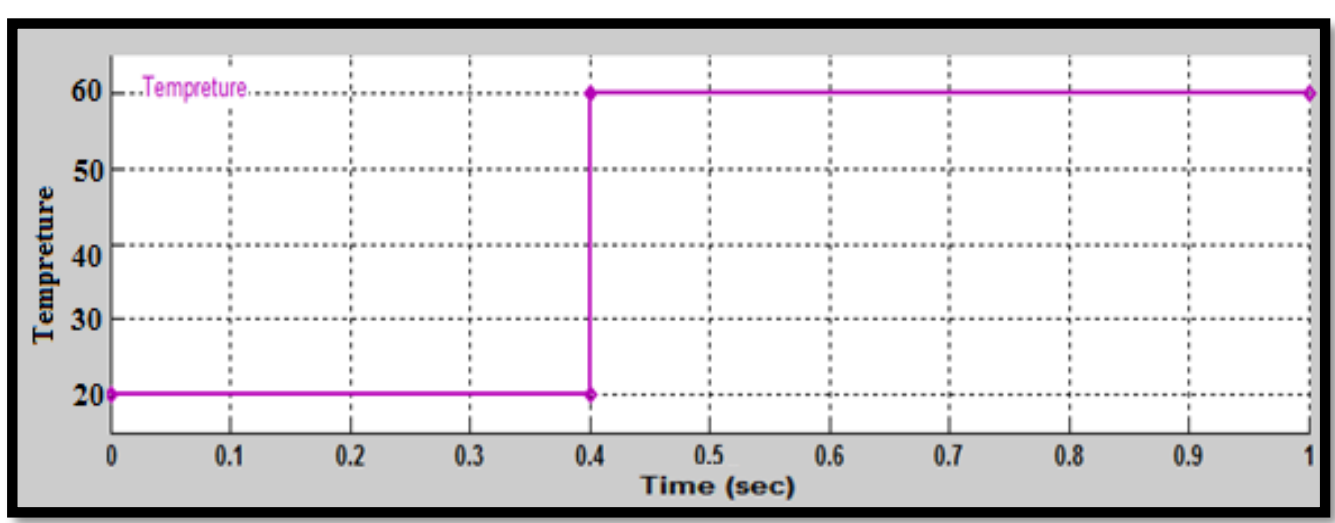

Figure 16: Variation of sun radiation

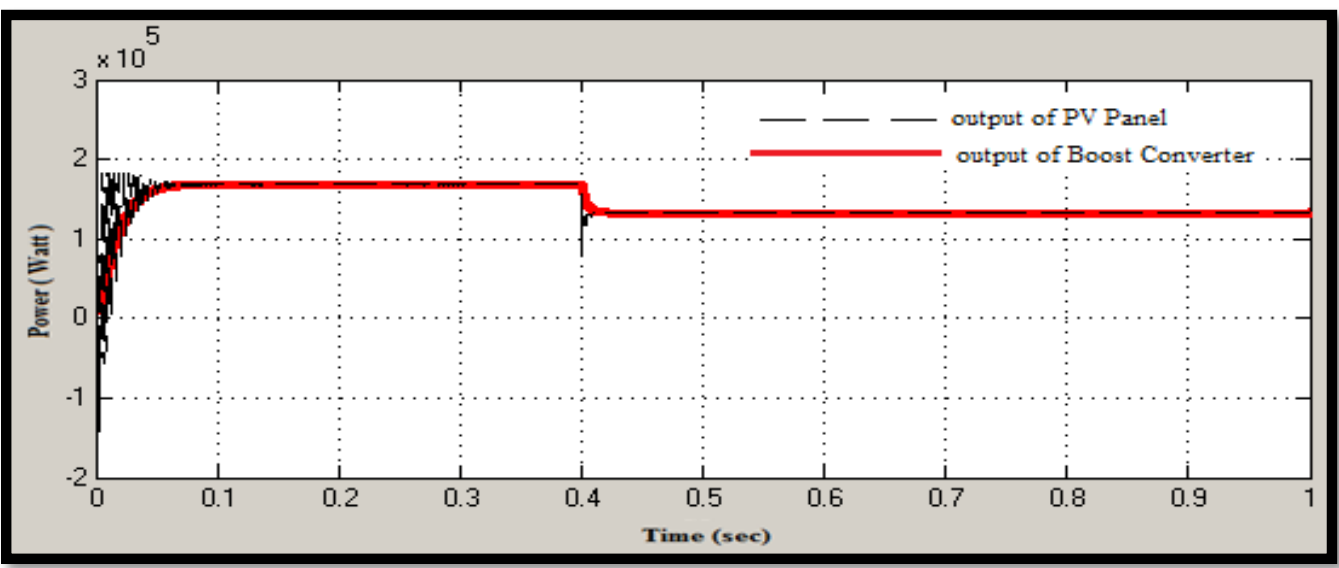

Figure 17: Output power of the Boost converter and output power of the PV panel

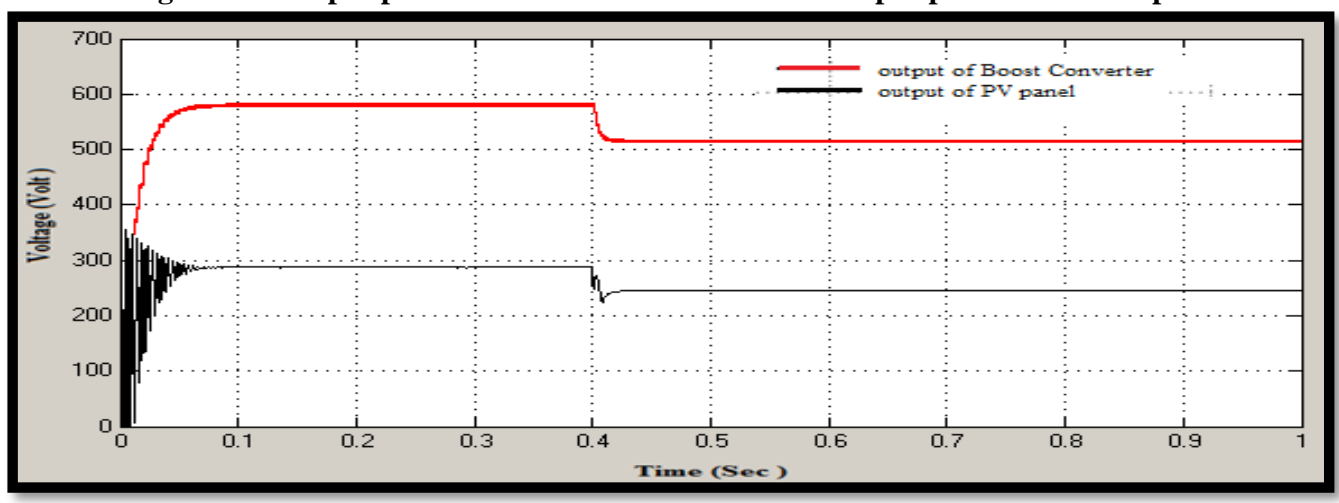

Figure 18: Output voltage of the Boost converter and output voltage of the PV panel 


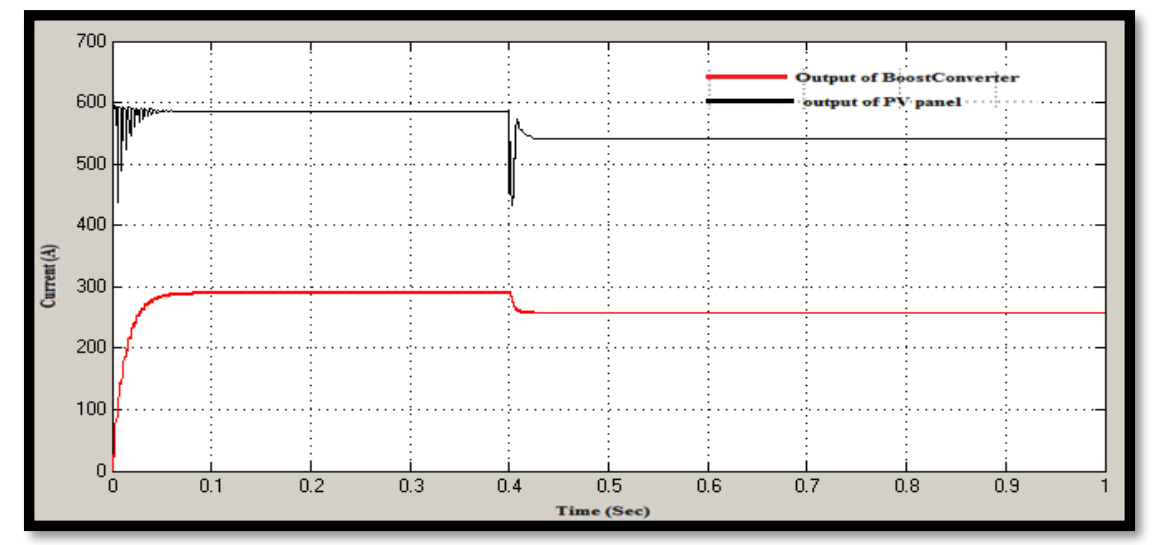

Figure 19: Output current of the Boost converter and output current of the PV panel

\section{Conclusions}

A standalone Photovoltaic system has modeled in Matlab/Simulink. For maximum power point tracking, the incremental conductance algorithm has used. The results obtained from the simulation show fast response with high accuracy of the MPPT algorithm under quickly increasing and decreasing of radiation conditions and temperature, but the algorithm of this technique has some complexity when compared to other technique.

\section{References}

[1]. T.Sridhar, \& J, A. k. , Development of Solar MPPT System Using Boost Converter with Microcontroller, International Journal of Advanced Research in Electrical, Electronics and Instrumentation Engineering, 1(4), (2012), 334-340.

[2]. Harini, M., Ramaprabha, R., \& Mathur, B.L., Modelling of grid-connected hybrid WIND/PV generation system using MATLAB, ARPN Journal of Engineering and Applied Sciences, 7(9), (2012), 11571161.

[3]. Saravana, S., Modelling and simulation of incremental conductance MPPT algorithm for photovoltaic applications, International Journal of Scientific Engineering and Technology, 2(7), (2013), 681-685.

[4]. Atallah, A. M., Abdelaziz, A. Y., \& Jumaah, R. S., Implementation of perturb and observe MPPT of PV system with direct control method using buck and buck-boost converters, Emerging Trends in Electrical, Electronics \& Instrumentation Engineering: An international Journal (EEIEJ), 1(1), (2014), 31-44.

[5]. Lokanadham, M., \& Bhaskar, K. V., "Incremental conductance based maximum power point tracking (MPPT) for photovoltaic system, International Journal of
Engineering Research and Applications (IJERA), 2(2), (2012), 1420-1424.

[6]. Jimenez-Brea, E., Salazar-Llinas, A., OrtizRivera, E., \& Gonzalez-Llorente, J., A maximum power point tracker implementation for photovoltaic cells using dynamic optimal voltage tracking, Paper presented at the Applied Power Electronics Conference and Exposition (APEC), (2010), Twenty-Fifth Annual IEEE.

[7]. Elbaset, A. A., Hussein, A. E.-E., Brisha, A., \& Mostafa, R. M., Implementation of a PICbased, Photovoltaic Maximum Power Point Tracking Control System, (ijetae) International Journal of Emerging Technology and Advanced Engineering, 4(5), (2014), 392-401.

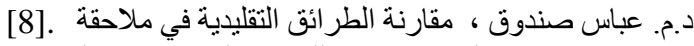
نقطة الاستطاعة العظمى في اللواقط الثمسية، مجلة الثقانة

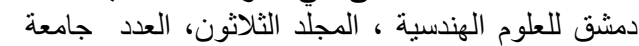
2014، الأول

[9]. Pazhampilly, R., \& Babu, S. S. N. R., Incremental conductance based MPPT for PV system using boost and SEPIC converter, ARPN Journal of Engineering and Applied Sciences, 10(7), (2015), 29142919.

[10]. Harish, A., \& Prasad, M., Microcontroller based photovoltaic MPPT charge controller, International Journal of Engineering Trends and Technology (IJETT), 4(4), (2013), 1018-1021.

[11]. Harjai, A., Bhardwaj, A., \& Sandhibigraha, M., Study of maximum power point tracking (MPPT) techniques in a solar photovoltaic array, Department of Electrical Engineering National Institute of Technology, Rourkela-769008, Orissa, (2011).

[12]. Priya, K. V., \& Kathir, I. Maximum Power Point Tracker for Sub watt Photovoltaic Module, International Journal of Innovative Research in Science, Engineering and Technology, 3(3), (2014), 162-166. 